\title{
E-Module Based Problem Solving in Basic Physics Practicum for Science Process Skills
}

\author{
https://doi.org/10.3991/ijoe.v15i15.10942 \\ Darmaji, Astalini, Dwi Agus Kurniawan ( $\left.{ }^{凶}\right)$, \\ Hanaiyah Parasdila, Iridianti \\ Universitas Jambi, Jambi, Indonesia \\ dwiagus.k@unja.ac.id \\ Susbiyanto \\ Eotvost Lorand University, Budapest, Hungary \\ Kuswanto, Muhammad Ikhlas \\ Central Luzon State University, Science City of Munoz, Philippines
}

\begin{abstract}
This paper presents the research on e-modules is based on problem solving for science process skills. E-modules are made with the stages of development, implementation, and evaluation adopted from the Branch. The purpose to see the science process skills and physical education students' perceptions of Universitas Jambi after using e-module basic physics lab-based science process skills using the model of problem solving using kvisoft application.
\end{abstract}

Keywords -E-module, Problem Solving, Basic Physics, Science Process Skills

\section{Introduction}

The development of science and technology has led to a process of change in all aspects of life, including the world of education [1]; [2]. The need for services and opportunities for learning improvement for students are the drivers of the emergence of educational reform. Therefore, education reform must always be carried out by pursuing learning processes that are in line with the times by utilizing Information and Communication Technology (ICT). The use of information and communication technology in learning can support and develop the skills of students both cognitive, affective and social skills of students, even higher skills [3]. So that the use of information technology in the learning process has become a necessity as well as a demand. The Law of the Republic of Indonesia Number 20 of 2003 concerning the national education system states that the learning process is a process of interaction between students and educators and learning resources in a learning environment. in [4], the teaching and learning process is a three-way relationship between the teacher, the material he/she uses and the students. So, learning resources are one of the factors that make students understand the concepts and material well. In addition, the quality of 
student interaction with learning resources has a profound effect on learning outcomes [5].

Learning resources are all things that can facilitate students in obtaining a number of information, knowledge, experience, and skills in the teaching and learning process. Teaching materials are a set of learning tools or tools that contain learning materials, methods, boundaries, and ways to evaluate systematically and attractively designed in order to achieve the expected goals, namely achieving competence or subcompetency with all its complexity [6]. These materials are very important in making knowledge accessible to students and can encourage students to engage with knowledge in various ways [7]. In [8], the author believe that Learning resources are instruments used in presenting and transmitting educational content to students. In addition, learning resources are also supporting materials available for use by teachers in classes and reading material for students [9]. The use of teaching materials in the learning process has benefits for students, among others, generating motivation, developing creativity, arousing prior knowledge, encouraging the process of understanding, thinking and logical reasoning, communication and interaction of students, and contributing to the development of different skills and the acquisition of values students, as well as retention of the desired knowledge, skills, and attitudes [10].

One of the learning resources used in learning carried out in the laboratory is a practicum module. The practicum module is a module compiled to assist in the implementation of practicum which contains the experimental title, objectives, theoretical basis, tools and materials, and questions that lead to goals following the rules of scientific writing [11]. Instructions for practicum as one of the learning resources in practical activities should be a guide for students in developing science process skills [12]. Science process skills are skills that make it easier for students to understand abstract concepts if they learn through concrete objects and are done alone by students through direct learning experience [13]. Therefore, it is important in the basic physics practicum guide to contain aspects of science process skills.

The practicum module that has been used in basic physics practices is modules in the form of printed modules. Teaching materials like this have not been maximized to meet the needs of students. Printed modules tend to be informative and less attractive which cannot display sound, video, animation, and images that can provide a clear explanation of the concepts conveyed. In today's technological development most students are more interested in teaching materials that utilize other media such as computers/laptops, even smart phones compared to teaching materials in the form of printed modules [14]. Therefore, it is necessary to modify printed module in the form of an electrical module or commonly called an e-module by using one ICT product in the form of software or program. Books have undergone metamorphosis from print to digital form so that it is operational more practical and can maintain book quality and will not be worn out from time to time [15]. In addition, the use of e-modules has the potential to change the views of students to read and consume interactively and make them comfortable, where the printed modules have images, narratives, and graphics but e-modules can contain various features such as audio, music, animation, and video [16]. 
One of the software used in converting printed modules in the form of flipbookshaped e-modules is the Kvisoft flipbook maker. The application of flipbook maker software is one of the applications that support it as a learning media that will assist in the learning process because the application is not only fixed on writings but it can be included in a motion animation, video, and audio that can make an interactive learning media interesting so learning becomes not monotonous [17].

Basic physics experiment module that has been modified into a form of e-modules using kvisoft application has many benefits, which can be accessed offline or online via Smartphone or tablet. Teaching materials developed using information and communication technology products can stimulate students' thoughts, feelings, concerns and interests in a process that is more effective [18]. Learning uses technology through teaching materials so that students can manage learning activities according to their flexible time and activities [19].

The purpose of this study is to develop teaching materials in the form of e-modules by using the kvisoft flipbook maker application and knowing how students' perceptions relate to the $e$-module that will be developed.

\section{Methodology}

This research is a development, implementation, and evaluation research with:

- In the development stage, the basic physics practicum module that is available is then made into a Kvisoft-based software design rule. Development of e-modules validated by experts to test the validity of the product and the final result of the emodule development process is the design of e-modules which will be implemented in the next process.

- In the implementation phase, problem solving based e-module based on basic physics using the prepared kvisoft application is implemented in accordance with its role and function as e-learning which can facilitate basic physics practicum in the hope that system users can use it well and can improve student understanding practicum material to be delivered. In addition, the use of kvisoft-based e-module can make it easier for students in terms of mobile-based use and can be carried everywhere without having to carry printed basic physics modules. The final result of the implementation process is a problem solving basic physics practicum module using the Kvisoft application that can help the basic physics practicum process for students.

- In the evaluation phase, the process carried out was to look at the science process skills of students and students' perceptions of the use of problem solving based physics practicum modules using the Kvisoft application using observation sheets and perception questionnaires.

Research on development, implementation, and evaluation used is adopted from Branch [20]. In this study drawn from 144 students from 300 students who contracted basic physics courses with the aim to see science process skills and perceptions of Jambi University physics education students after using problem solving based phys- 
ics basic e- module using the kvisoft application . The instruments used in this study were observation sheets and perception questionnaires. The observation sheet is used to measure science process skills of students with category $1=$ very bad, $2=$ not good, $3=$ good, and $4=$ very good. Science process skills observed are 16 indicators with a total of 60 statements. Whereas the perception questionnaire was used to determine students' perceptions of the use of Kvisoft-based basic physics E-module with a total of 20 statements with a range of categories $1=$ very low, $2=$ low, $3=$ moderate, $4=$ high, and $5=$ very high. For category perceptions questionnaire listed in Table 1:

Table 1. Category Perception students

\begin{tabular}{|c|l|}
\hline Interval & \\
\hline $20.0-36.0$ & Category \\
\hline $37.0-52.0$ & Not Good \\
\hline $53.0-68.0$ & Enough \\
\hline $69.0-84.0$ & Good \\
\hline $85.0-100.0$ & Very Good \\
\hline
\end{tabular}

Data obtained through observation sheets were analyzed using inferential statistics with t test (Independent sample t-test) with the help of SPSS 24 computer program. While perception questionnaire data were analyzed using descriptive statistics assisted by SPSS 24 computer program.

\section{$3 \quad$ Results and Discuss}

The results of the research conducted by this researcher are modifications to the basic physics practicum module based on science process skills using problem solving models that use the kvisoft flipbook maker application. In Indonesia, especially in practicum activities carried out at the Universitas Jambi, usually using a print-based guide book, therefore, the researchers made an innovation by making a Kvisoft flipbook-based electronic module that is used on students who take basic physics learning. Therefore, the novelty in this study is the change in printed teaching materials into Kvisoft flipbook-based electronics. This electronic module contains practicum material, work procedures, and practicum report formats which are all based on science process skills to be able to train or develop student science process skills. 


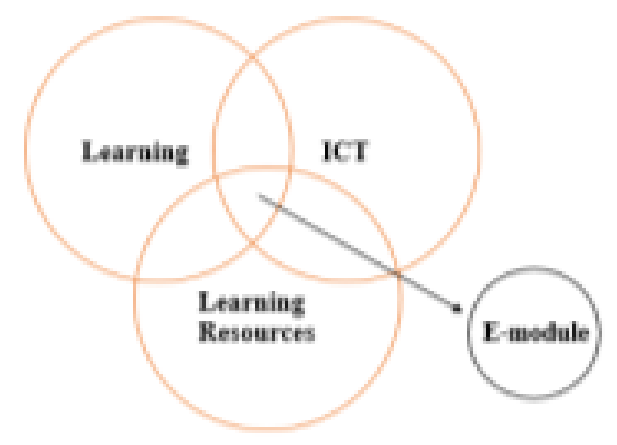

Fig. 1. Diagram of the Relation of Learning, ICT, and Learning Resources

Learning activities are designed so that students can actively construct concepts, laws or principles through the stages of observing, formulating problems, submitting hypotheses, collecting data, drawing conclusions and communicating concepts or principles found. As long as the learning activities take place, of course all students need learning resources as a tool that is used as a source of learning information. Teaching materials have various types consisting of printed and non-printed teaching materials. Print teaching materials consist of books, handouts, and modules.

Along with the advancement of information technology, teaching materials used in the learning process also develop and innovate for the advancement of education. One of the beneficiaries of information technology is the world of education. E-Learning processes can be defined as teaching-learning processes through support for information and communication technologies (ICT) [21]. The use of e-learning as teaching and learning tools is now rapidly expanding into education, with thousands of courses offered by educational institutions [22]. Education uses information technology as a learning medium, as well as increasing the capacity of lecturers and students to improve the quality of education. The most frequent type of learning resource used are: E-journal, E-book, E-module, full text database (aggregate), indexing and abstract database, reference database (biography, dictionary, directory, encyclopedia, etc.), numerical and statistical databases, images and audio-visual resources [23]. All of these resources are an advantage, when you come to learning and teaching activities [23].

The use of information technology is one important factor that allows the speed of transformation of knowledge to students. Research by utilizing information and communication technology, one of which is the development of printed module teaching materials into electronic-based modules, better known as E-Modules.

The final form of problem solving based physics practicum e-module using the modified Kvisoft application is as follows. 


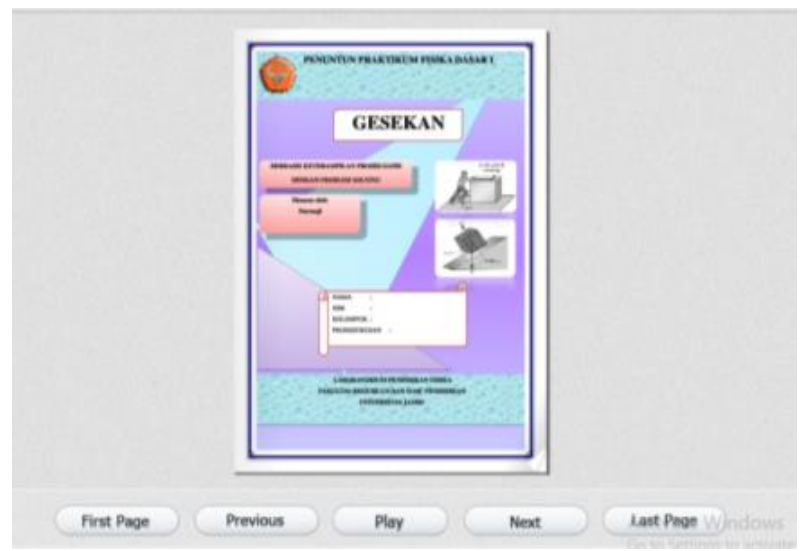

Fig. 2. Cover of E-Module

Figure 2 is the cover of an e-module for basic physics practicums with friction material

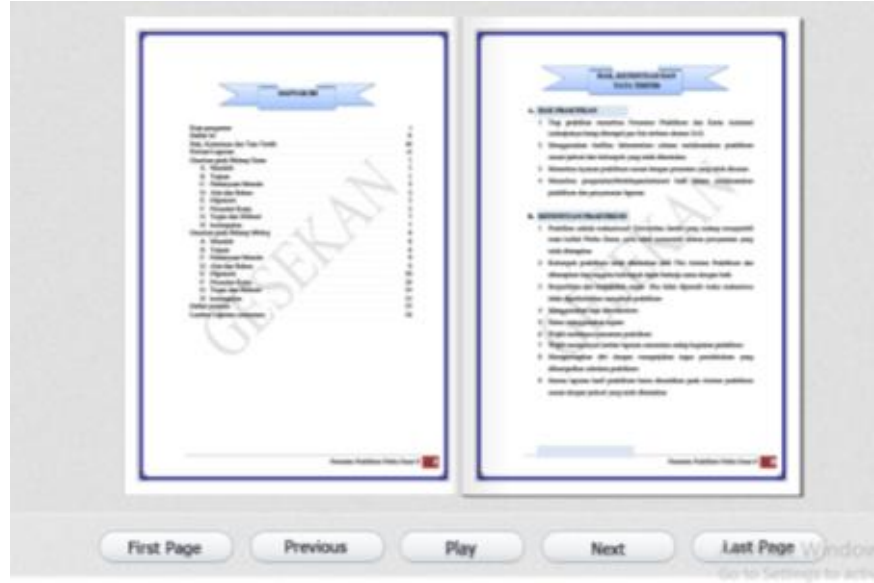

Fig. 3. Table of Contents of E-Module

Figure 3 is a table of contents contained in the e-module for basic physics practicum with friction material 


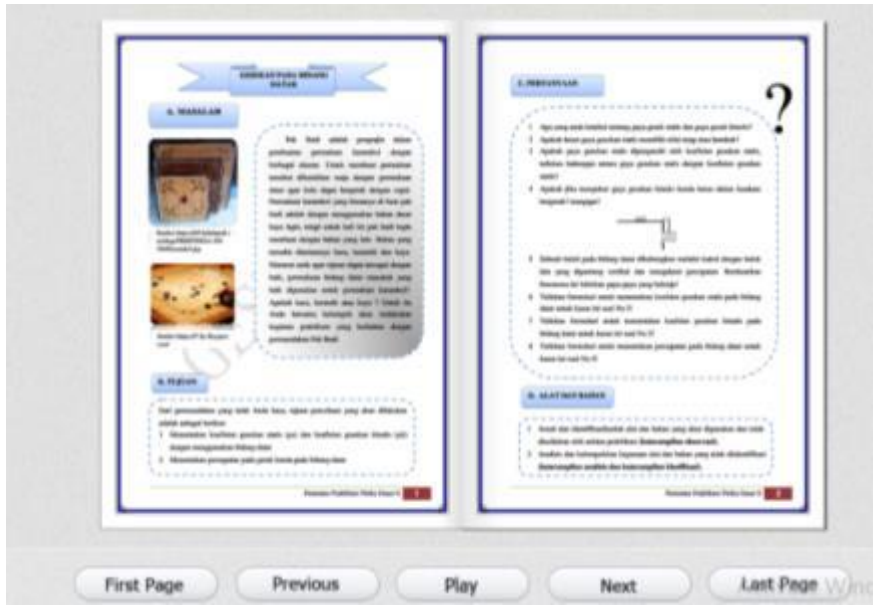

Fig. 4. Fig. 4 Material of E-Module

Figure 4 is the material contained in the e-module for basic physics practicums with friction material

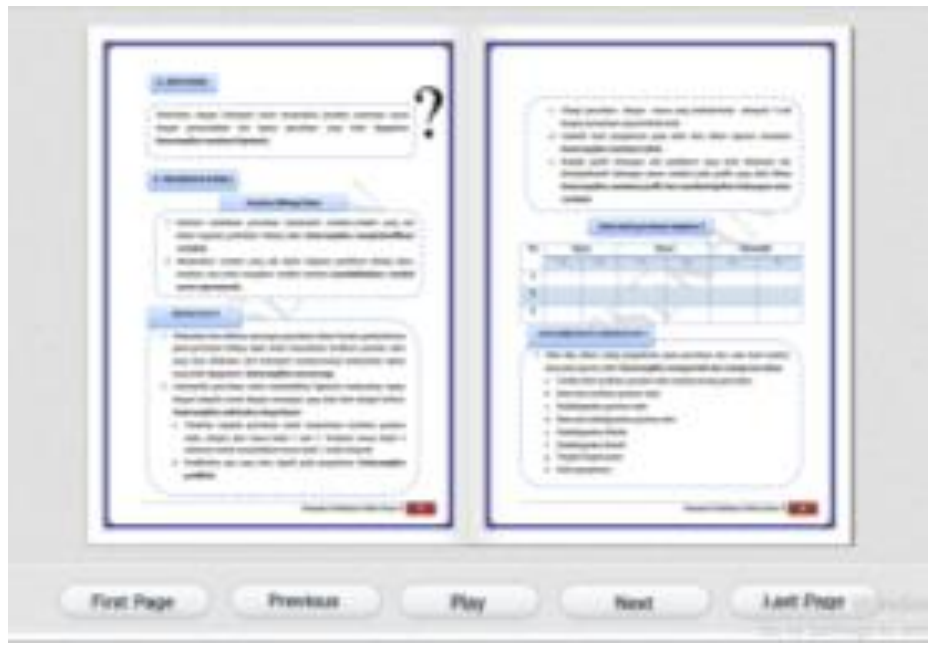

Fig. 5. Work Procedures of E-Module

Figure 5 is a research procedure used in the e-module for basic physics practicums with friction material 


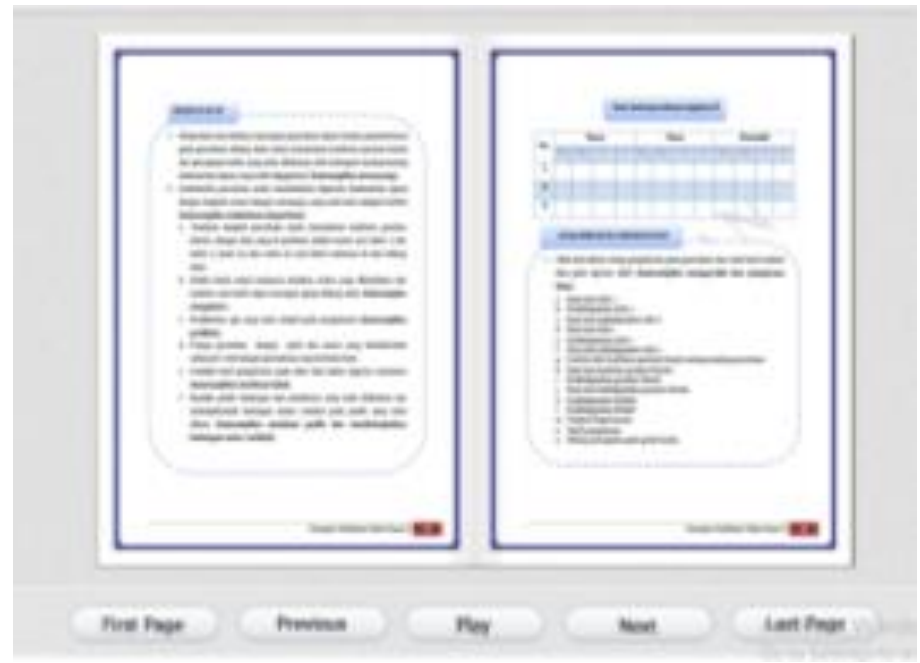

Fig. 6. Data Analysis of E-Module

Figure 6 is a data analysis used using e-modules for basic physics practicums with friction material

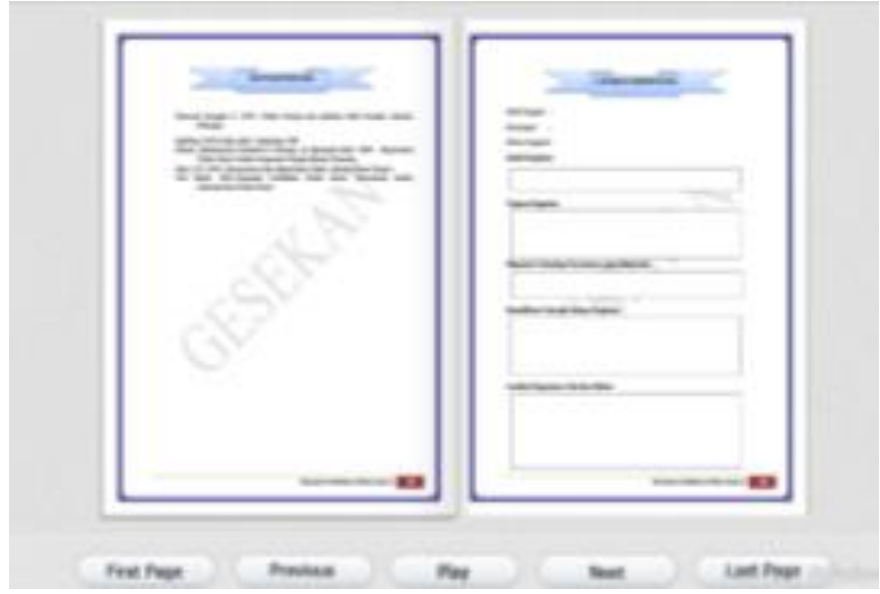

Fig. 7. References of E-Module

Basic physics practicum modules based on science process skills supported by the use of problem solving models are validated beforehand to experts. Based on the validation that has been carried out, suggestions are obtained to revise the product so that a product that is feasible to be used as a learning device with maximum results is achieved. The product revision suggested by experts is the use of language in experimental procedures to be more communicative language. Based on a standard e-book, which says about content elements, where the content page should use the use of lan- 
guage that is easy to understand and communicative [24]. After obtaining validation and being feasible to use as a learning device, the implementation phase is implemented. Implementation is carried out in small groups to find out student perceptions of modified guides. The implementation was carried out to 144 students who took basic physics practicum out of a total of 300 students.

After the basic physics e-module based on problem solving using the Kvisoft application modified, basic physics based e-module based on problem solving using the Kvisoft application was implemented in a small group of students in basic physics practicum to see science process skills and student perceptions of e-use kvisoft based module. Practical activity was more effective in fostering students of the acquisition of science process skills [25]. The following is presented the results of student perceptions analyzed using descriptive statistics shown in table 2.

Table 2. Students' Perception

\begin{tabular}{|c|c|c|c|c|c|c|c|}
\hline \multicolumn{3}{|c|}{ Category } & \multirow{2}{*}{ Mean } & \multirow{2}{*}{ Std. Deviation } & \multirow{2}{*}{ Min } & \multirow{2}{*}{ Max } & \multirow{2}{*}{$\%$} \\
\hline Interval & Attitude & Total & & & & & \\
\hline $20.0-36.0$ & Very Not Good & 0 & \multirow{5}{*}{3.6394} & & \multirow{5}{*}{39} & \multirow{5}{*}{95} & 0.0 \\
\hline $37.0-52.0$ & Not Good & 9 & & & & & 6.3 \\
\hline $53.0-68.0$ & Enough & 45 & & 0.48502 & & & 31.3 \\
\hline $69.0-84.0$ & Good & 67 & & & & & 46.5 \\
\hline $85.0-100.0$ & Very Good & 23 & & & & & 15.9 \\
\hline TOTAL & & 144 & & & & & 100 \\
\hline
\end{tabular}

From table 2, which came from 144 respondents from physics education program in universitas jambi and processed results using the SPSS program application, it was perceptions to e-module have a good category of $46.5 \%$ for a67 total of 144 students, enough at $31.3 \%$ for a total of 45 out of 144 students, very good at $15.9 \%$ for a total of 23 out of 144 students, and not good at $6.3 \%$ for a total of 9out of 144 .

Based on student perception data collected from perception questionnaires at Jambi University Physics Education students, it can be seen that students' perceptions of using basic physics based e-module based on problem solving using Kvisoft application are high with a mean value of 3.6394 supported by low standard deviation values 0.48502 which means that the use of e-modules for students is very needed and helpful. e- module is often conferred to be more effective than face-to-face learning [26].

This is because the use of problem solving based physics basic e-module using the Kvisoft application is simpler in its use than carrying printed modules. The advantages of e-module as a particular medium is a more effective than printed module [27].

Based on the results of the data from the observation sheet of science process skills in Jambi University Physics Education students after using problem solving based physics basic e-module using the Kvisoft application analyzed using inferential statistics with the help of the SPSS 24 program. Hypothesis testing carried out in this study was using independent sample test t-test. The results of the analysis using the t-test are presented in the following table II: 
Table 3. Independent Sample t-test

\begin{tabular}{|l|c|c|c|c|c|c|}
\hline & \multirow{2}{*}{$\mathbf{T}$} & \multirow{2}{*}{$\mathbf{d f}$} & \multirow{2}{*}{ Mean } & \multirow{2}{*}{ Std.Deviation } & 95\% confidence interval \\
\cline { 5 - 7 } & & & & & Lower & Upper \\
\hline $\begin{array}{l}\text { Student perceptions in e- } \\
\text { modules }\end{array}$ & 19.624 & 144 & 3.0906 & .24321 & 18.234 & .6120 \\
\cline { 2 - 7 } & 19.624 & 138.067 & 2.2033 & .30015 & 17.985 & .8615 \\
\hline
\end{tabular}

From table 3 it can be seen that the value of $t$ obtained ( $\left.t_{\text {count }}\right)$ with $t_{\text {table }}$ values. The value of $t_{\text {table }}$ can be found in table 3 statistics at the significance of 0.025 (2-sided test) with degrees of freedom (df) 144. In this study the results for $t_{\text {table }}$ are 1.97658. While for the value of $t_{\text {count }}$ can be seen in table 3. (Column $t$ ) which is 19,624. The hypothesis testing criteria is the value of $t_{\text {count }}$ is greater than the value of $t_{\text {table, }}$ there is a rejection of $\mathrm{HO}$ [28]. So, it can be concluded that there are significant differences in mastery of science process skills between physics education students who use Kvisoft-based e-modules and do not use basic physics practicum e-modules. It can be seen from table 3 that the mean value of students 'science process skills is 3.0906, which means that the use of e-modules can train students' science process skills.

Based on the data obtained from the implementation of process-based e-modules, it can be seen that the use of e-modules is effective in training student science processing skills. This is based on e-module is part of e-learning, where the use of $e$ learning in learning makes the learning process can be carried out continuously. Besides that E-learning is a solution in offering various possibilities for social networks so that in this way the teacher can store various records of student interactions in collaborative learning [16]. And students are motivated to learn in class because of the comfortable laboratory space that makes students eager to go to the laboratory [29].

Through learning to use products from information and communication technology various multimedia services can be easily transferred, such as audio, video, graphics that have high resolution so that the thinking process can lead to thinking [29]; [30]. Added also the advantages of using e-learning is that students can interact not only in two directions but can be done multi-purpose. where science use skills can be used through e-modules, where the use of e-modules utilizes media such as computers/laptops, events that make smart phones students interested and motivated [31]; [32].

\section{Conclusion}

The results of this study can be seen that problem solving based physics practicum e-module uses the kvisoft application. Based on implementation data, the perceptions of students in using e-modules based on Kvisoft are in the high category, which means that the use of e-modules is more interesting in conducting basic physics practicum activities. This also makes students' science process skills in the good category. With this problem -based basic physics practicum e-module using the Kvisoft application can enhance and train student science process skills. 


\section{Acknowledgement}

We would like to thank to head of laboratory, Physics Education' lecturers, and students who helped this research.

\section{References}

[1] Astalini, Kurniawan, D. A., Perdana, R., \& Kurniawan, W. (2019). Identification Attitudes of Learners on Physics Subjects. EST Journal of Educational Science and Technology, 5(1), 39-48. https://doi.org/10.26858/est.v5i1.8231

[2] Kurniawan, D, A., Astalini., \& Anggraini,L. (2018). Evaluasi Sikap SMP Terhadap IPA di Kabupaten Muaro Jambi. Jurnal Ilmiah Didaktika: Media Ilmiah Pendidikan dan Pengajaran. 19(1), 123-139.

[3] Hidayat, H., Kusumaningrum, I., \& Mardin, A. (2017). Needs Analysis of Entrepreneurships Pedagogy of Technology and Vocational Education with Production Base Learning Approach in Higher Education. International Journal on Advanced Science, Engineering and Information Technology, 7(5), 1701-1707. https://doi.org/10.18517/ijaseit.7.5. $\underline{1510}$

[4] Kyriakides, L. \& Creemers, B. P. M. (2008). "Using a Multidimensional Approach to Measure the Impact of Classroom Level Factors upon Student Achievement: a Study Testing the Validity of the Dynamic Model”. School Effectiveness and School Improvement, 183-306. https://doi.org/10.1080/09243450802047873

[5] Butcher. (2006). Designing Learning: From Module Outline to Effective Teaching, Oxford: Routledge. https://doi.org/10.4324/9780203968482

[6] Fajriah, Ulfah Nur, Madziatul Churiyah, (2016). Utilizing InstructionalMedia for Teaching Infrastructure Administration, Journal ofEducation and Practice, Vol.7, No.6.

[7] Linda, R., Herdini, H., \& Putra, T. P. (2018). Interactive E-Module Development through Chemistry Magazine on Kvisoft Flipbook Maker Application for Chemistry Learning in Second Semester at Second Grade Senior High School. Journal of Science Learning, 2(1), 21-25. https://doi.org/10.17509/jsl.v2i1.12933

[8] Bušljeta, R. (2013). Effective Use of Teaching and Learning Resources. Czech-Polish Historical and Pedagogical Journal, 5(2), 55-70. https://doi.org/10.2478/cphpj-2013-0014

[9] Bizimana, D., \& Orodho, J. A. (2014). Teaching and learning resource availability and teachers' effective classroom management and content delivery in secondary schools in Huye District, Rwanda.

[10] Harrison, F. (2003). Using learning resources to enhance teaching and learning. Center For Education Development: London

[11] Hofstein, A., \& Lunetta, V. N. (2004). The laboratory in science education: Foundations for the twenty-first century. Science education, 88(1), 28-54.https://doi.org/10. $\underline{1002 / \mathrm{sce} .10106}$

[12] Gobaw, G. F., \& Atagana, H. I. (2016). Assessing Laboratory Skills Performance in Undergraduate Biology Students. Academic Journal of Interdisciplinary Studies, 5(3), 113. https://doi.org/10.5901/ajis.2016.v5n3p113

[13] Karamustafaoğlu S (2011). Improving the Science Process Skills Ability of Science Student Teachers Using I Diagrams. Eurasian J. Phys. Chem. Educ. 3(1):26-38.

[14] Irwansyah, F. S., Lubab, I., Farida, I., \& Ramdhani, M. A. (2017, September). Designing Interactive Electronic Module in Chemistry Lessons. In Journal of Physics: Conference Se- 
ries (Vol. 895, No. 1, p. 012009). IOP Publishing. https://doi.org/10.1088/17426596/895/1/012009

[15] Divayana, D. G. H., Santiyadnya, N., Ratnaya, I. G., Sudirtha, I. G., \& Darmayasa, I. P. (2019). Digital book for assessment and evaluation courses based on Kvisoft-kelase asynchronous pattern. TELKOMNIKA, 17(1), 328-336.https://doi.org/10.12928/telko mnika.v17i1.9764

[16] Nindy Apsari, A., \& Kustijono, R (2017). Development Of E-Book Using Kvisoft Flipbook Maker To Train Science Process Skill For Senior High School Students In Curriculum 2013. Inovasi Pendidikan Fisika, 6(3).

[17] Fonda, A., \& Sumargiyani, S. (2018). The Developing Math Electronic Module With Scientific Approach Using Kvisoft Flipbook Maker Pro For Xi Grade Of Senior High School Students. Infinity Journal, 7(2), 109-122.https://doi.org/10.22460/infinity. v7i2.p109-122

[18] Yondri, S., Irfan, D., Putri, M., Zaus, M. A., \& Islami, S. (2019). Evaluation of Packet Tracer Application Effectiveness in Computer Design Networking Subject. International Journal on Advanced Science, Engineering and Information Technology, 9(1), 54-59002E. https://doi.org/10.18517/ijaseit.9.1.5931

[19] Idris, N., Hashim, S. Z. M., Samsudin, R., \& Ahmad, N. B. H. (2017). Intelligent learning model based on significant weight of domain knowledge concept for adaptive e-learning. International Journal on Advanced Science, Engineering and Information Technology, 7(42), 1486-1491. https://doi.org/10.18517/ijaseit.7.4-2.3408

[20] Branch, R. M. (2009). Instructional design: The ADDIE approach (Vol. 722). Springer Science \& Business Media. https://doi.org/10.1007/978-0-387-09506-6

[21] Aoki, K. (2010). The Use of ICT and e-Learning in Higher Education in Japan. World Academy of Science, Engineering \& Technology, 66, 868-872.

[22] Martínez-Caro, E., Cegarra-Navarro, J. G., \& Cepeda-Carrión, G. (2015). An application of the performance-evaluation model for e-learning quality in higher education. Total Quality Management \& Business Excellence, 26(5-6), 632-647. https://doi.org/10.1080/ 14783363.2013 .867607

[23] Anshari, M., Alas, Y., \& Guan, L. S. (2016). Developing online learning resources: Big data, social networks, and cloud computing to support pervasive knowledge. Education and Information Technologies, 21(6), 1663-1677. https://doi.org/10.1007/s10639-0159407-3

[24] Sohn, W. S., Ko, S. K., Lee, K. H., Kim, S. H., Lim, S. B., \& Choy, Y. C. (2001). Standardization of eBook documents in Korean industry. Computer Standards \& Interfaces , 4560. https://doi.org/10.1016/S0920-5489(01)00103-9

[25] Noesgaard, S. S., \& Ørngreen, R. (2015). The Effectiveness of E-Learning: An Explorative and Integrative Review of the Definitions, Methodologies and Factors That Promote eLearning Effectiveness. Electronic Journal of E-learning, 13(4), 278-290.

[26] Nwagbo, C., \& Chukelu, U. C. (2011). Effects of biology practical activities on students' process skill acquisition. Journal of the Science Association of Nigeria (JSTAN), 46(1), 58,70 .

[27] Welsh, E. T., Wanberg, C. R., Brown, K. G., \& Simmering, M. J. (2003). E-learning: emerging uses, empirical results and future directions. International Journal of Training and Development, 7(4), 245-258. https://doi.org/10.1046/j.1360-3736.2003.00184.x

[28] Cramer, D. (2003). Advanced quantitative data analysis. McGraw-Hill Education (UK).

[29] Karyotaki, M., \& Drigas, A. (2015). Online and other ICT Applications for Cognitive Training and Assessment. International Journal of Online and Biomedical Engineering.11(2), 36-42. https://doi.org/10.3991/ijoe.v11i2.4360 
[30] Xing, Lifu. (2018). Evaluation of Physical Education Multimedia Teaching for Data Assimilation. International Journal of Online and Biomedical Engineering. 14(4). 30-42. https://doi.org/10.3991/ijoe.v14i04.8366

[31] Romero, S., Guenaga, M., Garcia-Zubia, J., \& Orduna, P. (2015). Automatic Assessment of Progress Using Remote Laboratories. International Journal of Online and Biomedical Engineering. 11(2), 49-54. https://doi.org/10.3991/ijoe.v11i2.4379

[32] Astalini, Kurniawan, D. A., Perdana, R., \& Kurniawan, W. (2019). Identification Attitudes of Learners on Physics Subjects. EST Journal of Educational Science and Technology, 5(1), 39-48. https://doi.org/10.26858/est.v5i1.8231

[33] Kurniawan, D, A., Astalini., \& Anggraini,L. (2018). Evaluasi Sikap SMP Terhadap IPA di Kabupaten Muaro Jambi. Jurnal Ilmiah Didaktika: Media Ilmiah Pendidikan dan Pengajaran. 19(1), 123-139.

[34] Astalini, A., Kurniawan, D. A., Sulistiyo, U., Perdana, R., \& Susbiyanto, S. (2019). EAssessment Motivation in Physics subjects for Senior High School. International Journal of Online and Biomedical Engineering (iJOE), 15(11), 4-15. https://doi.org/10.3991/ijoe. $\underline{\mathrm{v} 15 \mathrm{i} 11.10843}$

\section{$7 \quad$ Authors}

Darmaji is associate professor and member Group Research ASPS (Attitude towards Physics and Science Processing Skills).Physics Education Program, Universitas Jambi, Jalan Raya Jambi - Ma. Bulian, KM 15, Mendalo Indah, Jambi, 36361, IndoPaper-E-Module Based Problem Solving in Basic Physics Practicum for Science Process Skills nesia. Her research interest include E-Assessment and Evaluation specially in Attitude Towards Physics and Science Processing Skills (Email: darmaji@unja.ac.id).

Astalini is associate professor and leader Group Research ASPS (Attitude towards Science and Science Processing Skills). Because attitude towards science is very important for life now, students who have the attitude of science are needed in the present because modern society is very dependent on science. Science Education Program, Universitas Jambi, Jalan Raya Jambi - Ma. Bulian, KM 15, Mendalo Indah, Jambi, 36361, Indonesia. Her research E-Assessment and Evaluation specially in Attitude towards Physics and Science Processing Skills. (Email: astalinizakir@unja.ac.id)

Dwi Agus Kurniawan is a lecturer and member of the ASPS Group Research (Attitude towards Science and Science Processing Skills). His research interest includes E-Assessment and Evaluation especially in Attitude towards Physics and Science Processing Skills. The age level of a child will experience very much difference, both in the form of his mindset, his skills, his relationships, and his attitude as a student. For teachers, it is very useful to know the differences in the mindset of their students, and about their daily interactions, and the behavior of their students. Benefits that can be obtained are: can create the right classroom for students, can provide innovative and varied learning methods, can provide lessons on deep moral aqidah, and explain the consequences for those who violate certain rules. He works at Science Education Program, Universitas Jambi Indonesia. (Email: dwiagus.k@gmail.com) 
Susbiyanto is a doctoral student in Eotvost Lorand University, 1075 Budapest, Kazinczy U. 23-27, Budapest, 1075, Hungary (Email: susbiyanto@ caesar.elte.hu)

Kuswanto is a postgraduate student in Central Luzon State University, Science City of Munoz, Philippines (Email: Kuswanto@clsu.edu.ph).

Muhammad Ikhlas is a postgraduate student in Central Luzon State University, Science City of Munoz, Philippines (Email: muhammadikhlas@ clsu.edu.ph).

Hanaiyah Parasdila is a graduate students at universitas Jambi and member Group Research ASPS (Attitude towards Physics and Science Processing Skills).Science Education Program, Universitas Jambi, Jalan Raya Jambi - Ma. Bulian, KM 15, Mendalo Indah, Jambi, 36361, Indonesia. Her research interest include E-Assessment and Evaluation specially in Science Processing Skills (Email: hanaiyah24@gmail.com)

Irdianti is a graduate students at universitas Jambi and member Group Research ASPS (Attitude towards Physics and Science Processing Skills).Science Education Program, Universitas Jambi, Jalan Raya Jambi - Ma. Bulian, KM 15, Mendalo Indah, Jambi, 36361, Indonesia. Her research interest include E-Assessment and Evaluation specially in Science Processing Skills (Email: irdianti517@gmail.com).

Article submitted 2019-05-28. Resubmitted 2019-08-29. Final acceptance 2019-10-06. Final version published as submitted by the authors. 